\title{
POPULATION BALANCE MODEL APPROACH TO BALL MILL OPTIMIZATION IN IRON ORE GRINDING*
}

\author{
Patrícia Mundim Campos Faria ${ }^{1}$ \\ Luís Marcelo Tavares² \\ Raj K. Rajamani ${ }^{3}$
}

\begin{abstract}
The process of particle size reduction by grinding is inherently inefficient and involves high capital and operating costs. In particular, ball milling is one of the important unit operations in the iron ore pelletizing process. The mill product, due to its physical properties, determines the efficiency of subsequent stages of classification, filtration and pelletizing, thus impacting the quality of iron ore pellets. The work demonstrates the application of the population balance model in the optimization of a full-scale ball mil circuit grinding pellet fines with the aim to evaluate the optimal solids concentration to improve iron ore pellet quality. Initially, detailed experimentation was carried out in a $25.4 \mathrm{~cm}$ diameter batch mill and a relationship for mill scale-up using a linear population balance model in wet grinding systems was established. The selection and breakage parameters and the specific selection functions were determined for pellet feed iron ore. It was possible to identify the non-normalizable nature of the breakage functions of the ore studied, which were modeled properly. Afterwards, as a result of incorporating the specific selection functions and breakage functions into the linear population balance model, it was possible to predict product size distributions in the pilot and plant scale mills $(0.416$ and $5.18 \mathrm{~m}$ diameter, respectively) from data obtained in the $25.4 \mathrm{~cm}$ diameter mill. Finally, with this scaleup procedure it was possible to appraise the plant scale optimization via laboratory scale grinding mill tests. The effects of changing percent solids were assessed in order to improve the industrial mill performance and the optimal value should be in the range from 76 to $80 \%$.
\end{abstract}

Keywords: Population balance model; Optimization; Breakage and Selection functions. \section{Engineering, University of Rio de Janeiro, Rio de Janeiro, RJ, Brazil.}

Metallurgist Engineer, PhD, Associate Professor, Department of Metallurgical and Materials

3 Metallurgist Engineer, PhD, Professor, Department of Metallurgical Engineering, University of Utah, Salt lake City, Utah, United States.

\footnotetext{
* Contribuição técnica ao $44^{\circ}$ Seminário de Redução de Minério de Ferro e Matérias-primas, 15ํ Simpósio Brasileiro de Minério de Ferro e $2^{\circ}$ Simpósio Brasileiro de Aglomeração de Minério de Ferro, 15 a 18 de setembro de 2014, Belo Horizonte, MG, Brasil.
} 


\section{INTRODUCTION}

Grinding operations are of great importance to the mineral industries and in particular are one of the most important unit operation in the iron ore pelletizing process.

In the case of pelletizing plants, the mill product, due to their physical properties, determines the efficiency of the downstream operations, that include: classification, filtration and pelletizing, also impacting directly in the final quality of iron ore pellets.

Grinding circuits involve high capital and operating costs and are notoriously inefficient. Therefore, there is considerable room for improvement, which could reduce the processing costs. This is a topic of special interest to Vale, which has ten pelletizing plants in operation in Brazil and two in Oman.

Both the design (scale-up) and the optimization of ball mills can be carried out with the assistance of mathematical models.

In the past, most of the mill scale-up work was based, directly or indirectly, on the empirical Bond energy size reduction equation. This approach was used extensively in the minerals industry and in accordance to some researchers (Austin, Klimpel and Luckie [1]) Bond work index may be useful for mill design, but not for optimization of operating ball mills. The main limitations of Bond's equation are associated to the fact that it does not allow decoupling the contributions of the mechanical environment, the mill transport and size classification. As such, the empirical equation for specific energy calculation implicitly assumes that the breakage kinetics, transport through the mill and classification sub processes, are characterized by a single parameter, the work index $\left(\mathrm{W}_{\mathrm{i}}\right)$.

Several studies have been carried out in the development of detailed phenomenological grinding models derived from population balance considerations [2,3]. In these models the explicit accounting of grinding sub processes (size reduction kinetics, material transport in the mill and size classification) gives them significant advantage over the simpler energy size reduction equations. This type of model, in its complete form, is capable of describing the size distribution in a tumbling mill grinding as a function of time in batch grinding or steady state mill discharge in continuous mills. As such, according to this methodology the plant scale mill can be optimized via laboratory scale grinding mill tests.

The present work demonstrates the application of the population balance model approach to optimizing ball milling in iron ore grinding for pellet feed preparation, showing how information from batch grinding tests and proper measurements of residence time distributions of a pilot-scale and a continuous mill can describe continuous mill performance. It shows, however, that this required the introduction of a correction factor for the breakage rates which was a constant for each mill simulated.

\subsection{Ball Mill Model}

The population balance model may be expressed by Equation (1):

$$
\frac{d\left[H m_{i}(t)\right]}{d t}=-S_{i}(t) H \mathrm{~m}_{\mathrm{i}}(t)+\sum_{j=1}^{\mathrm{i}-1} \mathrm{~b}_{\mathrm{ij}} S_{j}(t) H \mathrm{~m}_{\mathrm{j}}(t)
$$

where: $S_{i}(t)$ is the size discretized selection function for each ith size interval that denotes the breakage rate per time or per $\mathrm{kWh} / \mathrm{t}-\mathrm{b}_{i j}$ is the size discretized breakage function that represents the breakage distribution of fragments produced in each size

\footnotetext{
* Contribuição técnica ao $44^{\circ}$ Seminário de Redução de Minério de Ferro e Matérias-primas, 15오 Simpósio Brasileiro de Minério de Ferro e 2ํ Simpósio Brasileiro de Aglomeração de Minério de Ferro, 15 a 18 de setembro de 2014, Belo Horizonte, MG, Brasil.
} 
class, $\mathrm{m}_{\mathrm{i}}(\mathrm{t})$ is the mass fraction of the material in each size interval $\mathrm{i}$ at any time $\mathrm{t}$ and $\mathrm{H}$ is the total mass of material to be ground.

The distinct advantage of Equation (1) is that the parameters $S_{i}(t)$ and $b_{i j}$ can be obtained directly by experimental data using simple graphical procedures [2].

According to findings first reported by Herbst and Fuerstenau [4], the $S_{i}$ is, to a good approximation, proportional to the specific power input to the mill $(\mathrm{P} / \mathrm{H})$ and then the previous equation can be rewritten in the normalized form as Equation (4) that yields the energy-normalized form of the batch grinding model:

$$
\begin{gathered}
S_{i}=S_{i}^{E}(P / H) \text { or } S_{i}^{E}(\text { tons } / k W h)=S_{i}\left(\text { hours }^{-1}\right) H(\text { tons }) / P(k W) \\
S_{i}=S_{1} \exp \left(-\sum_{j=1}^{J} \zeta_{j}\left[\ln \left[\sqrt{x_{i} x_{i+1}} / \sqrt{x_{1} x_{2}}\right]\right) \quad \mathrm{J}=1,2,3\right. \text { etc } \\
\frac{d\left[m_{i}(\bar{E})\right]}{d \bar{E}}=-S_{i}^{E} \mathrm{~m}_{i}(\bar{E})+\sum_{j=1}^{i-1} \mathrm{~b}_{i j} S_{j}^{E} \mathrm{~m}_{\mathrm{j}}(\bar{E})
\end{gathered}
$$

where: $S_{1}$ is the feed size selection function determined from a feed disappearance plot, $\zeta_{j}$ is adjustable parameters, $S_{i}^{E}$ is the specific selection function for the ith size interval, $\bar{E}$ is the specific energy input to the mill and is equal to the product of specific power, $\mathrm{P} / \mathrm{H}$, and grind time, $\mathrm{t}$.

A description of a continuous tumbling mill requires not only a description of the breakage kinetics, but also a mathematical description of material transport through the mill:

$$
m_{i, M P}=\int_{0}^{\infty} m_{i, B A T C H}(t) E(t) d t
$$

where: the continuous response, $\mathrm{m}_{\mathrm{i}, \mathrm{MP}}$, is considered to be an average of batch

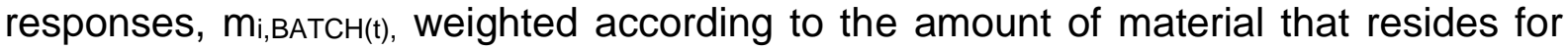
various times in the mill, $\mathrm{E}(\mathrm{t}) \mathrm{dt}$.

The residence time distribution in a mill, $E(t)$, may be represented with a highly flexible mixers-in-series model, i.e.,

$$
E(t)=\frac{N^{N}(t / \tau)^{N-1}}{\tau \Gamma(N)} \exp \left(-\frac{N t}{\tau}\right)
$$

where: $N$ is the mixing parameter which gives the equivalent number of mixers-inseries and $\tau$ is the mean residence time for material in the mill.

The residence time distribution, $\mathrm{E}(\mathrm{t})$, can be measured using a lithium chloride tracer. From the lithium chloride concentration response, the parameters $N$ and $\tau$ can be determined.

\section{MATERIALS AND METHODS}

\subsection{Equipment and Experimental Procedures}

In the present work, a relationship for mill scale-up using the population balance model in wet grinding system was established through detailed experimentation carried out in a $0.254 \mathrm{~m}$ batch mill diameter. In order to validate the methodology other two mills were used in this investigation: a pilot-scale ball mill $(0.416 \mathrm{~m}$ diameter) and Vale's industrial mill (5.18 m diameter), in operation in Vitoria, Espírito Santo, Brazil. The pilot-scale and the batch mills used were those installed in the Mineral Processing Laboratory at the University of Utah.

\footnotetext{
* Contribuição técnica ao 44 Seminário de Redução de Minério de Ferro e Matérias-primas, 15ํ Simpósio Brasileiro de Minério de Ferro e $2^{\circ}$ Simpósio Brasileiro de Aglomeração de Minério de Ferro, 15 a 18 de setembro de 2014, Belo Horizonte, MG, Brasil.
} 


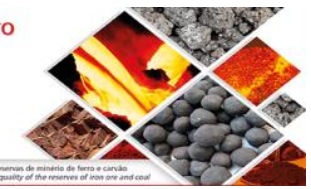

The material used was iron ore pellet feed acquired from Vale facility in Vitoria. The specific gravity was found to be $4.34 \mathrm{~g} / \mathrm{cm} 3$. The F80 was about $\sim 500 \mu \mathrm{m}$, with a top size of $6.7 \mathrm{~mm}$ (3-mesh).

In order to assess the particle size effect on the breakage function, experiments were carried out with two size fractions: $3.35 \times 2.36 \mathrm{~mm}(6 \times 8$-mesh) and $150 \times 106 \mu \mathrm{m}$ (100 x 150-mesh). In order to prepare these narrow-size samples, the "as received" iron ore was first sieved through a set of Sweco screens. The $+6,-8,+100$ and -150 mesh fractions were stored in different buckets. The product was further sieved for ten minutes through Tyler $\sqrt{2}$ interval screens to obtain the narrow size fractions of 6 x 8 and $100 \times 150$-mesh. Afterward, the sample was washed with water in order to remove fines.

\subsection{Batch Mill Experiments}

The procedure used in batch experiments in the $0.254 \mathrm{~m}$ mill using the mono-size and natural feed was the following: the mill was charged with balls and feed material in a layer loading manner that is, alternating layers of ball, feed and water, to ensure thorough mixing at the start of each test. The mill speed was adjusted to achieve $68.3 \%$ of critical speed, corresponding to $61.3 \mathrm{rpm}$. The feed material was wet ground considering $40 \%$ of ball load, $100 \%$ of slurry filling and the solids concentration in weight varied from 72 to $80 \%$. After reaching a particular grind, the mill was gently discharged over a grizzly. After filtration and drying the material, 500 grams was split out for sieve analysis. The sieving procedure consisted of dry screening for 20 minutes on Retsch AS 200 sieve shakers, 6 through 100-mesh, followed by wet screening for 8 minutes, 150 through 400-mesh. The sieved products were weighed and recombined with the balance of the ground material and then the entire charge returned to the ball mill for the next grinding interval. The mill rotational speed was recorded by a stroboscope and the torque was recorded on a Futek torque sensor connected to a computer.

\subsection{Pilot Mill Experiments}

The pilot mill was used to validate the use of population balance model as a predictive model. Once the solids and water flow rate were properly calibrated, the experimental procedure was very simple. The speed controller was set to the desired mill speed, the flow rate of solids and water were set to achieve a given slurry flow rate containing a desired solids concentration. The torque and weight of the slurry (hold up) contained in the mill were simply recorded at successive intervals of time. Once the weight recorded displayed values that did not show a consistent decreasing or increasing trend the steady-state flow condition was achieved. During steady-state operation three samples were collected during one minute in order to verify the solids flow rate and consequently the steady-state condition. Those samples were analyzed for particle size distribution and solids concentration. The experiments were carried out at a fixed feed rate at $1 \mathrm{~kg} / \mathrm{min}$, ball load of $35 \%, 68.3 \%$ of critical speed and different solids concentration (74, 76, 77, 79 and $84 \%)$.

\footnotetext{
* Contribuição técnica ao $44^{\circ}$ Seminário de Redução de Minério de Ferro e Matérias-primas, 15ํ Simpósio Brasileiro de Minério de Ferro e $2^{\circ}$ Simpósio Brasileiro de Aglomeração de Minério de Ferro, 15 a 18 de setembro de 2014, Belo Horizonte, MG, Brasil.
} 


\subsection{Residence Time Distribution (RTD) Measurement on the Pilot Mill}

The residence time distribution was measured using a lithium chloride tracer. Approximately 20 grams of lithium chloride dissolved in water was added to the feed stream. Subsequently the mill discharge was sampled following a specified time interval. The duration of sample collection was estimated to occur during at least three times the retention mean time. The slurry sample was kept in rest to settle the solids and the filtrate was then analyzed for parts per million of lithium chloride concentration according to a calibration curve (lithium chloride concentration versus conductivity), determined previously. From this lithium chloride concentration response the $\mathrm{N}$ and $\mathrm{T}$ shown in Equation (5) were estimated.

\subsection{Vale's Industrial Mill}

The grinding closed circuit at Vale pelletizing plant was sampled using Vale's standard procedure and the mass balance was done in order to calculate the classification curve. The RTD was measured according to the same procedure described above.

\subsection{Modeling Approach}

The relationships described above have been used for scale-up based on small scale batch tests. The estimation of the selection and breakage function parameters of a linear model was made using Estimill, a nonlinear regression program [3]. Figure 1 summarizes the methodology used for simulation, where the specific selection and breakage functions were originally estimated from the batch experiments. The residence time distribution, the mill power and the feed size distribution were then required to predict the size distribution of the mill discharge.

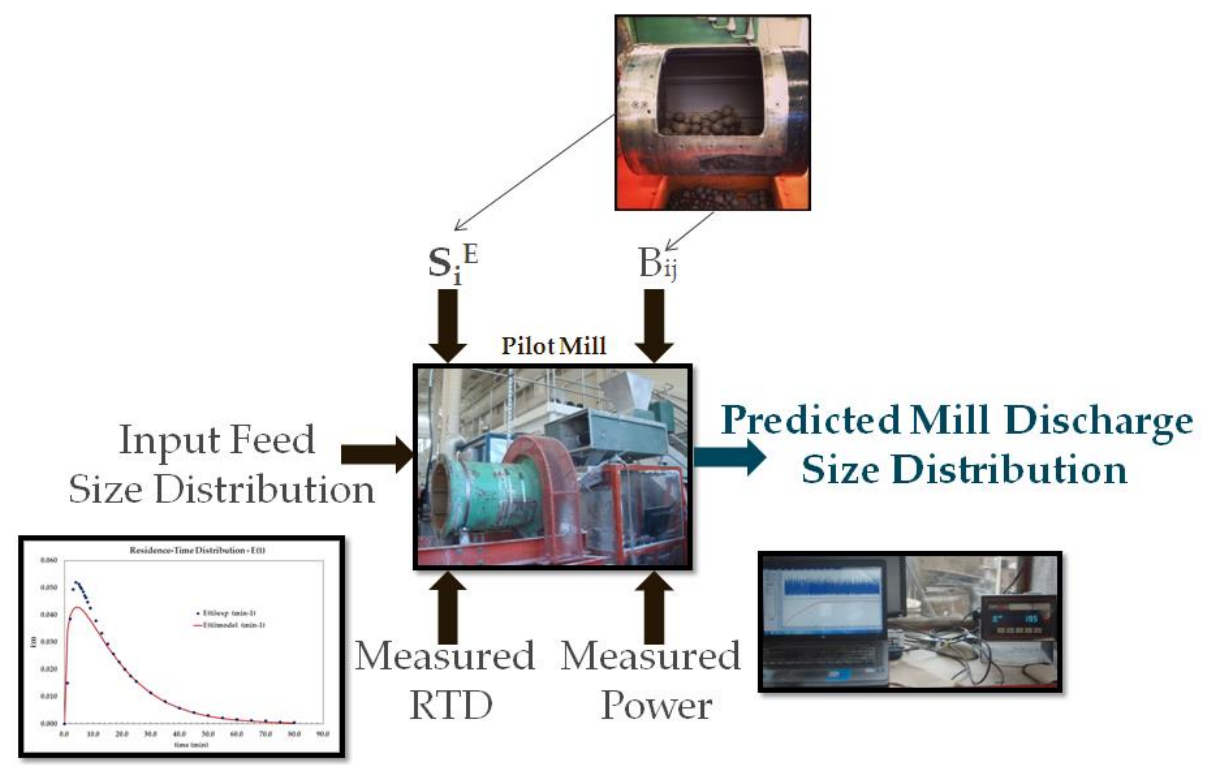

Figure 1. Prediction methodology scheme for the pilot scale mill.

* Contribuição técnica ao 44 Seminário de Redução de Minério de Ferro e Matérias-primas,

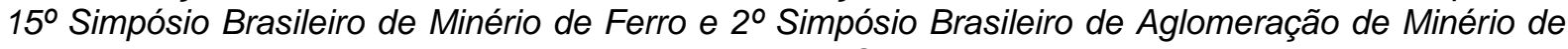
Ferro, 15 a 18 de setembro de 2014, Belo Horizonte, MG, Brasil. 


\section{RESULTS AND DISCUSSIONS}

As known wet grinding is inherently nonlinear, that is the selection and breakage functions generally depend on the size distribution existing within the mill as well as operating conditions. In this study the breakage functions estimated from batch wet grinding with $72 \%$ solids, $100 \%$ of slurry filling, $40 \%$ ball load and $68.3 \%$ critical speed, were considered to a good approximation invariant.

Figure 2 shows the breakage functions for the two sizes analysed, which demonstrate the non-normalizable nature of the ore breakage pattern. The figure also compares the measured results to the model fitting, which accounted for this non-normalizable character of the ore.

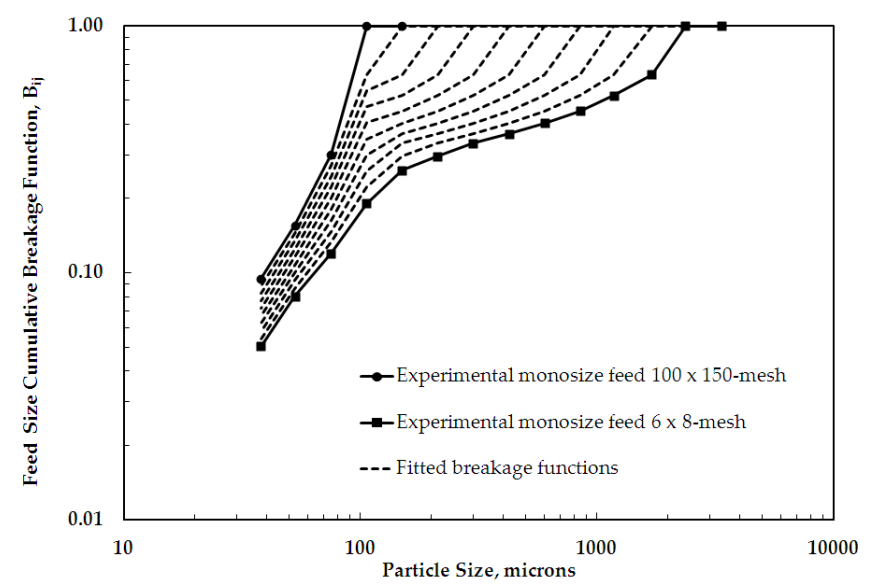

Figure 2. Experimental and fitted breakage functions for wet grinding in $25.4 \mathrm{~cm}$ diameter mill

The specific selection functions were estimated based on the so-called "similar fineness of grind procedure" for wet grinding scale-up, which encompassed the product size distribution from the larger mill. This is a type of linearization over product fineness [5], which assumes that, for the same fineness, the breakage and the specific selection functions will be approximately the same in different size mills. The agreement between experimental and predicted product size distribution showed in Figure 3 confirms the validity of this method.

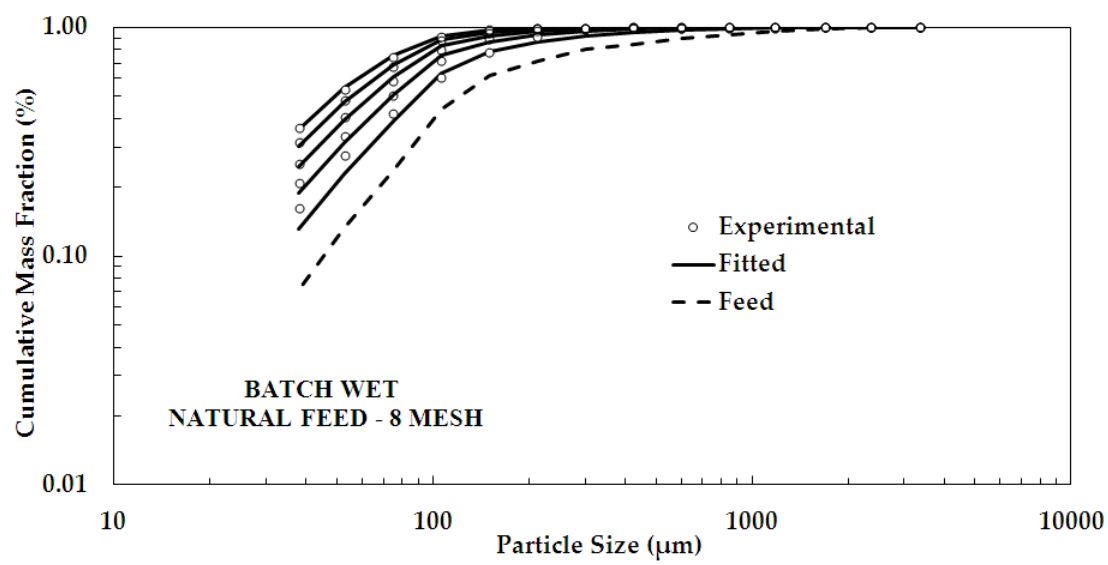

Figure 3. Comparison of experimental product size distribution and "similar fineness of grind" prediction for wet grinding in $25.4 \mathrm{~cm}$ mill ( -8 mesh feed) with $72 \%$ solids

\footnotetext{
* Contribuição técnica ao $44^{\circ}$ Seminário de Redução de Minério de Ferro e Matérias-primas, 15o Simpósio Brasileiro de Minério de Ferro e 2o Simpósio Brasileiro de Aglomeração de Minério de Ferro, 15 a 18 de setembro de 2014, Belo Horizonte, MG, Brasil.
} 
The selection functions fitted from results of the batch grinding experiments at different percent solids are presented in Figure 4, which demonstrate the effect of percent solids.

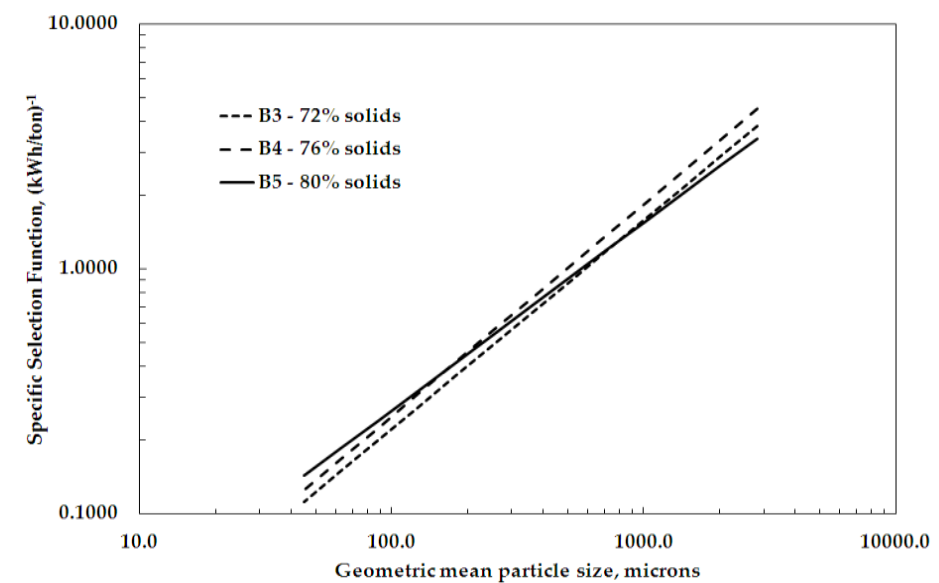

Figure 4. Dependence of specific selections functions on the operational conditions in $25.4 \mathrm{~cm}$ diameter mill.

The two parameters from the selection function $\left(\zeta_{1}{ }^{E}\right.$ and $\left.S_{1}{ }^{E}\right)$ were analyzed as a function of percent solids and results are presented in Figures 5 and 6 .

In order to validate the use of population balance model as a predictive model, selection function parameters fitted to data from the batch mill, and interpolated from Figures 5 and 6 , were used to predict the performance of the pilot-scale mill for different percent solids, but agreement was not satisfactory. This difference was attributed to liner design, which could have caused a vertical shift in the selection for any given percent solids. This is demonstrated in Figure 6, which shows that this shift corresponds to a fitting factor of about 0.9 , which should be multiplied to the batch data to predict the continuous mill operation.

Indeed, continuous industrial mill operation has been simulated and Figure 7 summarizes the variation of the amount of -38 microns and -45 microns produced in the mill for different percent solids. The quality of the iron ore pellet in the pelletizing process is directly related to the amount of fines in the product.

According to this particularity of the process and considering the ore type used during all experiments, Figure 7 can be used to identify the optimal operating condition for Vale's industrial mill, which should be in the range from 76 to 80 percent solids would be better to pelletizing process because the amount of fines generation (-38 microns) and also the amount of -45 microns (process target to achieve better product quality) were higher than other values simulated.

* Contribuição técnica ao 44 Seminário de Redução de Minério de Ferro e Matérias-primas, 15오 Simpósio Brasileiro de Minério de Ferro e 2ํ Simpósio Brasileiro de Aglomeração de Minério de Ferro, 15 a 18 de setembro de 2014, Belo Horizonte, MG, Brasil. 


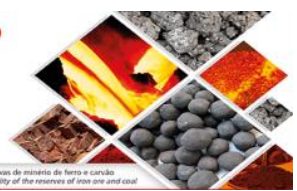

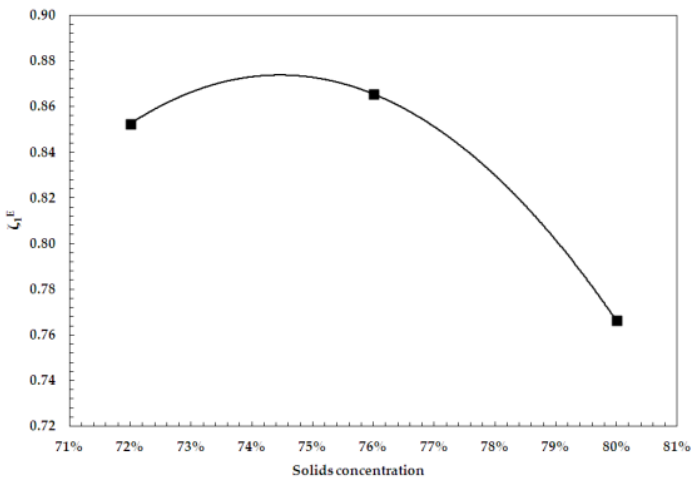

Figure 5. Relationship between solids concentration and $\zeta 1 \mathrm{E}$ from batch tests

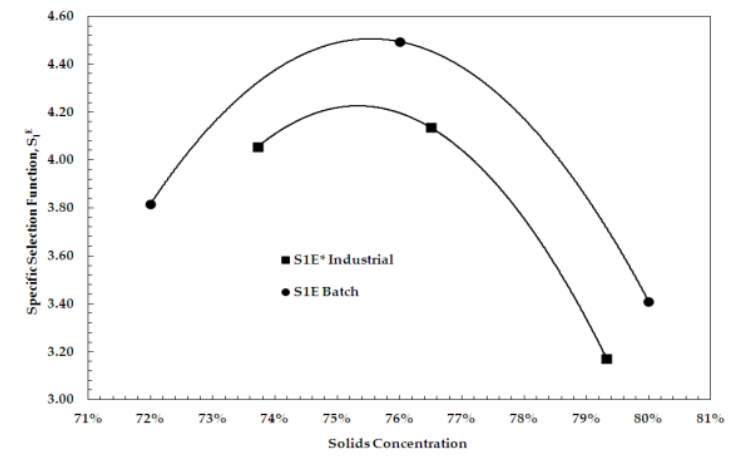

Figure 6. Relationship between solids concentration and feed size specific selection functions, $\mathrm{S}_{1} \mathrm{E}$

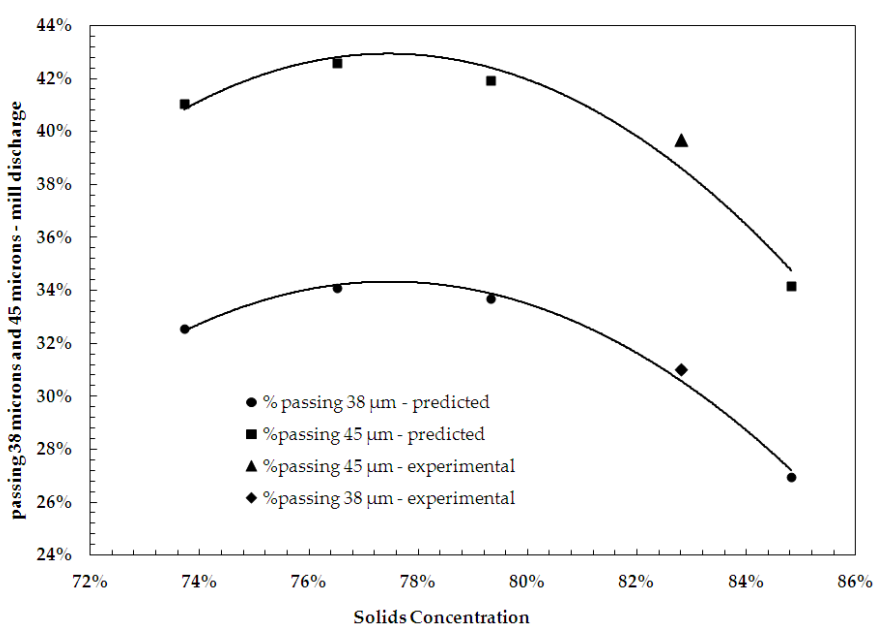

Figure 7. Product fineness of industrial mill discharge as a function of percent solids

\section{CONCLUSION}

Fitting the population balance model of batch grinding to data from a $25.4 \mathrm{~cm}$ mill in size reduction of an iron ore resulted in non-normalizable breakage functions and breakage rate distributions that varied with percent solids. From these, as well as a residence time distribution, it was possible to predict the product size distributions from a pilot scale mill operating in open circuit. This, however, required the introduction of a correction factor to the selection function which was explained on the basis of differences in liner design.

Considering the correction factor determined to scale-up the plant scale mill, it was possible to predict the product size distributions in Vale's industrial mill through the population balance model as well. It allowed to conclude that the range of solids concentration between 76 and $80 \%$ was optimal since the fines generation and the amount of -45 microns was the highest, which would favour the pelletizing process.

\section{Acknowledgments}

The authors would like to acknowledge with deep appreciation and gratitude the invaluable help of the whole team of Pelletizing Plants in Vale S/A that supported us in the development of this work.

\footnotetext{
* Contribuição técnica ao $44^{\circ}$ Seminário de Redução de Minério de Ferro e Matérias-primas, 15은 Simpósio Brasileiro de Minério de Ferro e $2^{\circ}$ Simpósio Brasileiro de Aglomeração de Minério de Ferro, 15 a 18 de setembro de 2014, Belo Horizonte, MG, Brasil.
} 


\section{REFERENCES}

1 Austin LG, Klimpel RR, Luckie PT. Process engineering of size reduction: ball milling, Society of Mining Engineers of the American Institute of Mining, Metallurgical and Petroleum Engineers, Inc., 1984, New York.

2 Herbst JA, Fuerstenau DW. The zero order production of fine sizes in comminution and its implications in simulation, Trans. AIME, 1968; 241: 538548.

3 Herbst JA, Rajamani K, Kinneberg DJ. (1977) Estimill - a program for grinding simulation and parameter estimation with linear models, Program Description and User Manual, Utah Comminution Center, University of Utah, Salt Lake City, Utah.

4 Herbst JA, Fuerstenau DW. Mathematical simulation of dry ball milling using specific power information, Trans. AIME, 1973; 254: 538548.

5 Herbst JA, Mika TS. (1973) Linearization of tumbling mill models involving nonlinear breakage phenomena, Eleventh International Symposium on Computer Applications in Mineral Industries, Tucson, Arizona.

* Contribuição técnica ao $44^{\circ}$ Seminário de Redução de Minério de Ferro e Matérias-primas, 15ํ Simpósio Brasileiro de Minério de Ferro e $2^{\circ}$ Simpósio Brasileiro de Aglomeração de Minério de Ferro, 15 a 18 de setembro de 2014, Belo Horizonte, MG, Brasil. 